\title{
The Strengthening of Role for the Traditional Institution through Preserving the Law Knowledge on the Sustainable Life in Moronene Hukaea Laea Traditional Society
}

Heryanti ${ }^{*}$, Herman, Guswan Hakim

Senior Lecturer at Faculty of Law, Halu Oleo University, JL HEA Mokodompit, Kampus Tridharma, Aundonohu, Kota Kendari, Sulawesi Tenggara, Indonesia

DOI: $10.36348 /$ sijlcj.2020.v03i11.012

| Received: 01.11.2020 | Accepted: 10.11.2020 | Published: 19.11 .2020

*Corresponding author: Heryanti

\section{Abstract}

The research objective is to determine the form of strengthening the role for a customary institution through the preservation of legal knowledge on maintaining the survival of the Moronene Hukaea Laea Indigenous People and to determine the effect of strengthening for the role of a customary institution on the preservation of legal knowledge on maintaining the survival of the Moronene Hukaea Laea Indigenous People. This research uses descriptive qualitative with empirical normative approach. The result of the research is a form of strengthening the role of traditional institution through preservation of knowledge on maintaining the survival of the Customary Law's Community Moronene Hukaea Laea, which is to routinely carry out tradition or traditional ceremony that has been passed down from old generation to young generation, including ceremonies for releasing the harvest and welcoming the planting year (mewusosoi), a ceremony to request permission from supernatural beings who guard the forest (ntiwonua) before land clearing (mo'ooli) and village purification ceremonies (montewehi) as well as supervision of customary institution for customary violation which it can be sanctioned by the customary institution according to customary rule. The influence of customary institution on the preservation of legal knowledge for maintaining the survival of the Customary Law's Community of Moronene Hukaea Laea, includes influence internally and externally. The influence of strengthening the role of customary institution internally, can improve the welfare of indigenous people. It can protect the existence of indigenous people.

Keywords: The Role for Customary Institution, Legal Knowledge, Survival, Traditional Society.

Copyright ( $) 2020$ The Author(s): This is an open-access article distributed under the terms of the Creative Commons Attribution 4.0 International License (CC BY-NC 4.0) which permits unrestricted use, distribution, and reproduction in any medium for non-commercial use provided the original author and source are credited.

\section{INTRODUCTION}

The development of life that is harmonized with the harmony of nature is one of the principles of life in the Indonesian customary law community. The concept of fulfilling needs without destroying nature has made Indonesian indigenous peoples, as environmentally friendly communities, characterized by local wisdom. Various forms of local wisdom of indigenous peoples in Indonesia have become knowledge to maintain the survival of indigenous peoples. Maintaining survival is intended to maintain harmony in the relationship between humans and nature. As long as humans protect nature, nature will also take care of human needs. Indigenous peoples in Indonesia, have knowledge of natural management, especially forests so that they are sustainable. Respect for nature in the form of traditional ceremonies, and medicines derived from nature. A healthy lifestyle has long been applied by indigenous people in Indonesia. Like placing a water jug. At each doorstep so that anyone must wash their hands and feet before entering the house.

The separation of customary forest from customary community through the concept of state forest, prior to the Decision Constitutional Court of 2015, resulted in indigenous people ensuring its welfare and the ecological sustainability of forest. According to Maria S.W. Sumardjono, the transformation process, also resulted in the elimination of local wisdom institution $\left[^{1}\right]$. The existence of an indigenous

\footnotetext{
${ }^{1}$ Maria S.W. Sumardjono, dkk. 2011. Pengaturan Sumber Daya Alam di Indonesia Anatar Yang Tersurat dan Tersirat, Kajian Kritis Undang-Undang Terkait Penataan Ruang dan Sumber Daya Alam, Fakultas Hukum UGM dan Gadjah Mada University Press. Yogyakarta, p. 30.
} 
community, it cannot be separated from customary institution as the highest institution which plays the role in regulating the lives of indigenous people. The development of society in general influences the lives of indigenous people, especially in terms of its relationship with natural resources. Customary institution is needed to maintain and preserve the pattern of life for indigenous people in order to protect nature. To support the existence of customary institution, it is necessary to strengthen customary institution, which is also regulated in Article 95 of Law of 6 of 2014 on Village, which contains rules to strengthen customary institution to carry out customary function.

The indigenous Moronene Hukaea Laea community in Bombana Regency has received recognition through the Regulation of Bombana Regency of 4 of 2015 on Recognition, Protection and Empowerment of the Moronene Hukaea Laea Indigenous People. This Regulation stipulates that customary institution is customary instrument in indigenous people who has the authority to enforce customary law in the Moronene Hukaea Laea Indigenous People. The area of the Moronene Hukaea Laea Indigenous People which is in the Rawa Aopa Watumohai National Park area implements the pattern of life of indigenous people based on local wisdom and is still guided by Indonesian national law. For this reason, it is necessary to strengthen the role of customary institution as the customary institution to be able to maintain and to preserve the life pattern of indigenous people.

This research aims to determine strengthening the role of customary institution through preservation of knowledge on maintaining the survival of the Customary Law of the Community of Moronene Hukaea Laea. Also to determine the influence of strengthening the role of customary institution on the preservation of indigenous peoples' knowledge to maintain the continuity of customary law in the Moronene Hukaea Laea Indigenous People.

\section{LITERATURE REVIEW}

\section{The Strengthening of the Role of Customary Institution in Indonesia}

The term "strengthening" in this research is all forms of response which are part of the modification of one's behavior to the behavior of others, which aims to provide information or feedback on their actions as an act of encouragement $\left[{ }^{2}\right]$. Furthermore, the term "role" has a meaning, namely a set of levels expected to be owned by those who are domiciled in society. The role is part of the main task that must be carried out $\left[{ }^{3}\right]$.

${ }^{2}$ Farida Rahim, 2008, Pengajaran Membaca Sekolah Dasar, Bumi Aksara, Jakarta, p.117.

${ }^{3}$ Kamus Besar Bahasa Indonesia, 2007, Balai Pustaka, Jakarta, p. 845.
Constitutionally, the recognition of the communities of customary law and their rights is stated in Article 18B paragraph (2) of the 1945 Indonesia Constitution that the state recognizes and respects the unity of indigenous people and their traditional rights as long as they are alive and in accordance with the principles of the Indonesian State, which are regulated in law. The customary community is a community unit in an autonomous customary area, where it regulate its life system independently (among others: law, politic, economy, etc.), is also autonomous, namely a customary community unit formed by the community itself, is not formed by other forces, for example the village unit with the Village Community Resilience Institution.

The regulation of the lives of indigenous people, it cannot be separated from the role of traditional institution in Indonesia. The definition of customary institution according to the Regulation of the Minister of Home Affairs of Indonesia of 5 of 2007 on Guidelines for the Structuring of Social Institution, is that the Customary Institution, is a Community Institution, either deliberately formed or fairly developed in certain indigenous communities within the Indonesian Territory. Customary institution has the right and authority to regulate, to manage and to resolve various life problem based on customs and customary laws. According to Ter Haar $\left[{ }^{4}\right]$, the customary law institution of Indonesia, is maintained by a decision of indigenous people, especially the the customary head's authoritative decision, which assists in the implementation of deeds according to the customary law or in the interest of the judge's decision who is in charge of adjudicating customary dispute. As long as this decision is not contrary to the legal beliefs of the indigenous people's Indonesia. Then the awareness of customary law is recognized. Customary institution becomes the community association which participates in socio-economic and religious structure as a form of representation of a community in development.

\section{The Indigenous People}

Customary community is group of people who is organized, lives in a certain area, has its own power, and has its own wealth in the form of visible or invisible object, where member of the unit experience life in society as normal according to the nature of nature and no one among its. The member has the tendency to dissolve the bond which has grown forever $\left.{ }^{5}\right]$. The form and structure of indigenous people which is customary association, its member is bound by factors that are territorial and geneological. Indigenous people or territorial customary association is permanent

\footnotetext{
${ }^{4}$ Soerjono Soekanto, 1983, Hukum Adat Indonesia, Raja Wali Press,Jakarta,p. 17.

${ }^{5}$ Husen Alting, 2010, Dinamika Hukum dalam Pengakuan dan Perlindungan Hak Masyarakat Hukum Adat Atas Tanah, LaksBang PRESSindo, Yogyakarta, hlm. 30. 
and regular community, whose community member is bound to a certain area, both in terms of worldly as a place of life and in spiritual terms as places of worship of ancestral spirit $\left[{ }^{6}\right]$. Meanwhile, a genealogical community or legal association is an orderly community unit, in which member is tied to the same lineage from one ancestor, either indirectly because of marital or customary ties $\left[{ }^{7}\right]$.

\section{Local Wisdom}

Local wisdom $\left[{ }^{8}\right]$ is an individual response to the surrounding environmental conditions. Indonesia's Law of 32 on 2009 on Environmental Protection, Article 1 paragraph 30 explains that local wisdom is the noble values that apply in the order of community life, including protecting and managing the environment in a sustainable manner. Suhartini $\left[{ }^{9}\right]$ in her research explained that the diversity of adaptation patterns to the environment that exist in Indonesian society which is passed down from generation to generation, becomes a guide in utilizing natural resources and the environment. This is the local wisdom of a community. Through this local wisdom, people are able to withstand various crises that have befallen them. It is important to study local wisdom in a society in order to maintain balance with its environment and to preserve the environment.

\section{RESEARCH METHOD}

This research uses empirical normative type of research. This type of normative research is a type of research which emphasizes the study of legal science and seeks to emphasize the prevailing legal principles regarding the role of customary institution. Furthermore, empirical research is the study of legal science to analyze the reality which occurs in society, especially in relation to the role of customary institutions in indigenous people. The research location, namely the customary institution of the Moronene Hukaea Laea indigenous community in Bombana Regency, Indonesia. The research sample was selected by purposive sampling, including the indigenous Moronene Hukae Laea community and customary stakeholders. The research data includes secondary data, including written legal materials. Primary data, including data obtained through participatory observation, survey and interview, as well as field diaries. All collected data were analyzed qualitatively interpretive.

\footnotetext{
${ }^{6}$ Hilman Hadikusuma, 2003, Pengantar Ilmu Hukum Adat Indonesia, CV Mandar Maju, Bandung:, p. 108.

${ }^{7}$ Ibid. p. 109.

${ }^{8}$ Ridwan, N.A. 2007. Landasan Keilmuan Kearifan Lokal, Ibda Jurnal Studi Islam dan Budaya. STAIN Purwokerto. Purwokerto. p. 7.

${ }^{9}$ H. Munir Salim, 2016, Adat Sebagai BudAya Kearifan Lokal Untuk Memperkuat Eksistensi Adat ke Depan, Jurnal Al Daulah, Vol. 5 / No. 2 / Desember 2016, p. 247.
}

\section{THE RESULT AND DISCUSSION Location Overview}

The indigenous Moronene Hukaea Laea community is an indigenous community located in Bombana Regency, Southeast Sulawesi Province, Indonesia. After going through a long process, finally the Moronene Hukae Laea indigenous people were recognized through the Regulation of Bombana Regency of 4 of 2015 on the Recognition, Protection and Empowerment of the Moronene Hukae Laea Indigenous People in Bombana.

The history of the Moronene Hukaea Laea indigenous people cannot be separated from the history of the first arrival of the Moronene people in Southeast Sulawesi. According to Abdul Rauf Tarimana $\left[{ }^{10}\right]$, the Moronene tribe is the oldest tribe inhabiting the mainland area of Southeast Sulawesi. The old village (tobu during the period of customary rule) was inhabited by the sixth generation of Moronene people in 1920. Hukaea Laea Village is also called Kampung Wukulu, which means seeds or agel bones because of the large number of agel plants in the area. Agel seeds are used for the needs of herbs to make a garden cottage or small house for resting. However, the houses made from agel seeds are no longer found after a lot of pressure on the Moronene Hukae Laea indigenous people, which was marked by the sweeping movement carried out by the government of Southeast Sulawesi Province, Indonesia.

Administratively, the area of the Moronene Hukaea Laea indigenous people is in the Rawa Aopa Watumohai National Park area. TNRAW was confirmed by the Decree of the Minister of Forestry of Indonesia Number 756 / kpst / II / 1990 on the Designation of the Aopa Watumohai Swamp Forest Group as a forest area with a national park function dated December 17, 1990 with an area of 105,194 ha, covering three districts namely Kolaka Regency, Buton Regency, and Kendari Regency.

The area of the Moronene customary territory based on the map of the Moronene territory or kingdom, which is called Alamu-I Bambana wita-I Moronene, is estimated to be around $3,973.67 \mathrm{~km}^{2}$. The area of the indigenous Hukaea Laea is estimated to be 3,000 ha. However, according to the opinion of the indigenous people of Hukaea Laea, according to historical evidence of the Hukaea Laea indigenous people, the area of the customary area of the Moronene people is estimated to be 13,000 ha. Based on the map of the boundaries of the territory and the mapping of Kampo Hukae Laea, as well as from the field survey and analysis in 2014, the area of the Hukaea Laea customary area, is estimated to be 26,295, 32 ha. The boundaries of the Moronene customary territory are:

\footnotetext{
${ }^{10}$ PD Aman, tanpa tahun, Komunitas Adat Moronene Kampo Hukaea Laea, p. 7-9.
} (C) 2020 | Published by Scholars Middle East Publishers, Dubai, United Arab Emirates 
1) To the north, it is bordered by Konawe Selatan Regency, Watumohai Mountains and Tawunalula.

2) In the south, it is bordered by Bombana Regency (Lombakari Village, Langkowala, Lantari Jaya).

3) To the west is bordered by Tangkeno (mountain) Mendoke.

4) The east is bordered by the Tiworo Strait.

The total population of the indigenous Moronene Hukae Laea community is 150 families, with 245 men and 248 women. The total population is 493 people. The topography of the Hukae Laea region is dominated by savanna, tropical rainforest, lowland and mangrove forests. The indigenous people of Moronene Hukae Laea have a livelihood of farming, gardening and rice fields $\left[{ }^{11}\right]$.

\section{Strengthening the Role of Customary Institutions through Preservation of Knowledge on Maintaining Survival in the Moronene Hukaea Laea Indigenous People}

The existence of indigenous people can only be recognized if it meet the requirements, as stipulated in statutory regulation. Article 67 paragraph (1) of Law of 41 of 1999 on Forestry, stipulates that customary communitiy is recognized if its existence meets the following elements:

1. The community is still in the form of a community (rechtgemeenschap);

2. There are institutions in the form of customary rulers;

3. There is a clear customary law area;

4. There are legal institutions and instruments, especially customary courts, which are still adhered to; and

5. They still collect forest products in the surrounding forest area to fulfill their daily needs.

Ethnic Moronene are indigenous people who live based on their ancestral origins over an indigenous territory, who have sovereignty over land and natural resources, socio-cultural life governed by customary law and customary institutions that manage the sustainability of their community life $\left[{ }^{12}\right]$.

Indigenous peoples are communities that have their own uniqueness as members of the community which are formed territorially or geneally, and carry out self-management in the existing apparatus in society, which is called customary institutions. The right of indigenous peoples to own and manage their own affairs through customary institutions is recognized in

${ }^{11}$ Data for 2019, source: Clerk (Secretary) of the Moronene Indigenous Institute, Hukaea Laea.

${ }^{12}$ Academic Manuscript of the Bombana Regency Regional Regulation Number 4 of 2015, p. 4.
Article 18B paragraph (2) of the 1945 Indonesian Constitution. Further reinforcement in Article 28I paragraph (3) of the 1945 Indonesian Constitution. The academic text of Perda No. 4 of 2015 states that the affirmation contained the constitution further strengthens the existence of customary institutions as one of the collective rights of indigenous peoples inherent in the human community $\left[{ }^{13}\right]$.

The United Nations Declaration on the Rights of Indigenous Peoples (UNDRIP) in Article 4 provides that: "Indigenous peoples in the exercise of their right to self-determination, have the right to autonomy or selfgovernment in matters that with regard to their internal and local affairs, as well as the means and means of funding their autonomous functions". Then Article 5 of the UNDRIP regulates that indigenous peoples have the right to maintain and strengthen their different characteristics in the political, legal, economic, social and cultural institutions, while maintaining their right to participate fully, if they wish, in life. political, economic, social and cultural countries.

The indigenous Moronene Hukaea Laea community has a customary institution as the highest institution that regulates indigenous peoples based on their customary law. Customary institutions are the highest adat apparatus, which have the authority to enforce customary law in the Moronene Hukaea Laea Community. The institutional structure and tasks of the Moronene Hukaea Laea indigenous people, namely:

1) The head of Kampo, has a duty as the highest leader in the Kampo and is responsible for everything in the Kampo adat;

2) Bonto (customary judge), has the duty as a customary judge who resolves cases in the community;

3) Pabitara (community relations), served as advisor in the community;

4) Juru Tulis (secretary), in charge of writing the administration of the Kampo in assisting the duties of the head of the Kampo and responsible to the head of the Kampo;

5) Kungkuno sosoroma (treasurer), is in charge of collecting customary products in the form of customary tax money and is responsible to the head of the village;

6) Totongano inalahi (forestry sector), is responsible for protecting and preserving the forest;

7) Totongano lombo (plantation sector), tasked with regulating the plantation sector of indigenous peoples so as not to violate the provisions of customary law;

8) Totongano Kadadi (animal affairs sector), has the duty to protect and supervise animals, both wild and domestic animals; 
9) Pembuea (health sector), is in charge of are sick, including treating animals and plants;

10) Рии Tobu (head of the hamlet), in charge of assisting the head of the village in carrying out his duties as a leader in the tobu;

11) Sarea (the head of the neighborhood unit), is in charge of helping Puи Tobu take care of the community;

12) Tamalaki (security sector), is in charge of providing security in customary areas and is directly responsible to the head of the village.

A customary institution led by a head of a customary institution called a mokole. The customary institution of the Moronene Hukaea Laea has the following powers:

1) Representing indigenous people in the interests of indigenous people;

2) Manage customary rights and customary assets to improve the progress and standard of living of the community.

3) Resolving problem relating to civil and minor criminal cases at every level of organization or institution, as long as the cases does not conflict with the prevailing law in Indonesia.

The lives of indigenous people is influenced by the forest environment which is the source of life for indigenous people. Customary forest that is in customary territories is highly protected by customary community where the management procedures has been regulated by customary law. For indigenous people, maintaining the forest is the same as protecting the main source of life for indigenous people. This role is one of the authorities of the customary institution $\left[{ }^{14}\right]$.

Managing nature well is part of the traditional knowledge possessed by the indigenous Moronene Hukaea Laea community. Traditional knowledge according to $\mathrm{M}$. Hawin is knowledge developed by indigenous communities or intellectual works based on tradition $\left[{ }^{15}\right]$. This knowledge is used by one generation to the next, which develops. Traditional knowledge includes methods of cultivation and processing of crops (agriculture), medicine, medicine, food and beverage recipes, arts and so on. Knowledge about maintaining survival in the indigenous Moronene Hukaea Laea community is knowledge possessed by indigenous peoples related to maintaining, maintaining and managing the fulfillment of life necessities. Traditional knowledge is part of the local wisdom of indigenous

\footnotetext{
${ }^{14}$ Interview with Mansur Lababa, 31 October 2020.

${ }^{15}$ S. Bahri, 2014, "Legal Protection of Traditional Knowledge as Community Asset Maslahah Mursalah Perspective", Thesis, Maulana Malik Ibrahim State Islamic University, Malang, $\quad$ p. $27 . \quad \mathrm{http}: / /$ etheses.uinmalang.ac.id/339/6/10220087\%20Bab\%202.pdf., Accessed
} on 2 November 2020. carrying out treatment if there are people who

peoples. Knowledge about maintaining survival in the indigenous Moronene Hukaea Laea community, is maintained and maintained by traditional institutions, namely routinely carrying out tradition or ceremony $\left[{ }^{16}\right]$.

Preservation of traditional knowledge by customary institution is part of strengthening the existence of customary institution because customary ritual can only be carried out by customary institution. Likewise, the implementation of indigenous people's knowledge is still under the supervision of customary institution, so that if there is a custom violation, the customary institution can be penalized according to customary rules. The knowledge of the indigenous Moronene Hukaea Laea community includes knowledge about forest management and land clearing, gardening procedures, including medicine.

Land clearing is an activity of using forest areas for gardening, farming or rice fields. Land clearing must first follow a customary procession carried out by a customary institution. The indigenous people of Moronene Hukaea Laea group their customary forests into $\left[{ }^{17}\right]$ :

1) Inalahi pue, namely sacred forest, is the core zone of a dense and broad jungle and has never been cultivated by humans. Inalahi pue is believed to reside in a forest guardian spirit (ntiwonua) so that it should not be disturbed. In addition, sacred forests are a source of springs (Mata Bundu), small and large rivers $(l a a)$ and animal resting places.

2) Inalahi popalia is a buffer forest that is believed to be inhabited by spirits and has not been disturbed by human from generation to generation. In this popalia there are spring, plant and medicine, bath for medicine and animal shelter. Indigenous people does not dare to enter this forest area without going through a customary procession first.

3) Inalahi peuma (plantation forest) is a former plantation forest that can be processed by the community at any time because it has been abandoned and returns to forest.

4) Olobu (small forest) is a small forest group in the middle of a field with rare trees and animals that are rarely found in that place.

5) Kura (cultivation) is a former garden or field that has been cultivated.

6) Lueno (meadow) is a large expanse of grass.

7) Bako (mangrove) is a natural pond that is harvested once a year.

\footnotetext{
${ }^{16}$ M. Hawin, 2009, "Protection of Traditional Knowledge in Indonesia", Draft Inauguration Speech for Professor of the Faculty of Law, Gadjah Mada University, Yogyakarta, Gadjah Mada University, p. 2.

${ }^{17}$ Academic Manuscript of the Bombana Regency Regional Regulation Number 4 of 2015, p. 33-36.
} 
8) Peo (salt pond), namely salt pond located in the Hukaea Laea customary area which is managed collectively through customary processions.

9) Bolo (traditional fish pond), which is a natural pond located in the Hukaea Laea customary area which is managed collectively through customary procession.

Traditional knowledge carried out for land clearing in this forest area is peuma, that customary community members who will get lombo (land) after being deemed appropriate, and able to manage their land, and do not have customary (adat), will get the approval of customary institution. To determine a good and fertile location, a traditional mekilala ceremony is held by the village. The land was determined before it was opened, so that there would be no disturbance from spirit with supernatural power, the mo'ooli ceremony was held by the village. Mo'ooli is a traditional ceremony by providing conditions for spirit who is believed to be forest guard for the land to be cleared. Customary forest will be cleared or used for human activity, so human must first ask permission from supernatural beings who inhabit the forest. The natural sign interpreted as a sign or answer from a supernatural being (ntiwonua) is a good sign or the land is allowed to be used when butterflies (tolewa), grasshoppers (kotumba), and tasia (butterfly) appear flying around the ooli. It is considered a bad sign or does not get permission from the ntiwonиa, namely when a large red wasp (roani) appears (towua motaha) and a small yellow wasp (kokoti). If a sign appears that is not allowed, then the Mo'ooli ceremony is performed again as the ritual requesting supernatural powers with the hope that if the spirits want to be moved or not. If the second ceremony has been carried out but there is still a sign of not being allowed to appear, then the indigenous community member is not allowed to clear land in that area and move it to another land until he gets permission from the ntiwonua $\left[{ }^{18}\right]$.

At every harvest in the customary area, the ceremony to release the harvest year and welcoming the planting year (mewusosoi) is carried out by the customary institution. The harvest result is gratitude for the indigenous people, so that through the traditional ritual of mewuwusoi, an expression of gratitude to the ruler of nature. It is hoped that through the procession, the indigenous people will still receive blessing and protection for the next harvest. The role of customary institution is to strengthen the sense of togetherness of indigenous people to jointly engage in the customary procession to welcome the harvest ${ }^{19}$.

The knowledge of how to garden the Moronene Hukaea Laea customary community as an

\footnotetext{
${ }^{18}$ PD Aman Bombana, 2018, hlm. 21. Loc. Cit.

19 Interview with the Head of the Moronene Customary Institution, Hukaea Laea, Mansur Lababa, 31 October 2020.
}

agricultural community, is to use the forest through the clearing of plantation land to meet their daily needs. Land clearing is still being carried out by moving. Plantation land clearing is divided into $\left[{ }^{20}\right]$ :

1) Tangka turtle is former garden or field that has been cultivated and then the processor is moved to another location. This former garden will be processed back into a garden after the transfer is carried out in several places. The utilization period of the tangka turtle is usually 5 to 10 years, depending on the fertility of the soil.

2) Kura ea is the former garden/field which has been cultivated for 1 to 10 years, then abandoned with a wide expanse (lowo lue).

3) Kura ate is a former garden that was once cultivated with a small stretch (lowo ote) and then abandoned for 1 to 5 years.

4) Hinuarako turtle is former garden that was once cultivated and is just at the planting stage. The owner passed away, so the plantation could not be continued. If the rice has been planted, for some reason it cannot be used as seeds for the next planting stage.

5) Kura sailela is a former garden that was once cultivated by pioneering (umawu) or logging (monea), the owner has died, so the garden must be abandoned and cannot be planted.

6) Tinalui is a garden that has been planted and then the produce is harvested twice. The prevailing control and management of land in customary territories in the Moronene Hukaea Laea customary community is communal ownership, not individual ownership. The control and regulation of land that is managed for gardening, farming or rice fields is carried out by customary institution based on hereditary habit.

The authority to control and regulate customary institution also includes the authority to give customary sanction for any violation in customary territories. Every action which enters this territory is the perpetrator, either individually or collectively, will be sanctioned, that is, it is employed in designated places such as the customary hall, mosque, house, school and other public facilities while awaiting the decision of the customary assembly. The same sanction is also imposed for violation of this territory in popalia without the permission of the customary institution and in this case it is peuma for cultivating land without the permission of the customary institution $\left[{ }^{21}\right]$.

In addition to knowledge in land management systems and gardening activities which are always influenced by spiritual beliefs, so that all actions of indigenous people must ask permission from the natural ruler, the Moronene Hukaea Laea indigenous people

\footnotetext{
${ }^{20}$ Academic Manuscript of the Bombana Regency Regional Regulation Number 4 of 2015, p. 44-45.

${ }^{21}$ PD Aman Bombana, 2018, hlm. 17-18. Loc. Cit.
} 
also believes that everything that befalls humans such as disease, reinforcement or calamities is also affected. magical things. The indigenous people of Moronene Hukaea Laea divide diseases into two, namely common diseases and diseases that arise due to magic. Magical disease is a disease commonly suffered by residents due to weather changes and germs. Then disease due to magic is a disease that is believed by the population due to violation of customs $\left[{ }^{22}\right]$.

Treatment includes internal and external medicine using medicinal plant whose property has been known and passed down from generation to generation. Indigenous people who lives a natural lifestyle has high immunity to various diseases that is acquired from consuming forest sweet potatoes. During the Covid-19 pandemic, it is not a concern for indigenous people because indigenous people has implemented a healthy lifestyle by consuming healthy food from natural plants. Likewise, the habit of washing hands has long been applied to the habit of cleaning themselves when returning home. Even indigenous people thinks this pandemic does not exist in its customary environment $\left[{ }^{23}\right]$.

Diseases that arise due to violations of customary institutions carry out the montewehi ceremony, which is a ceremony to clean the village from violations that are intentionally or unintentionally committed by indigenous peoples. This ceremony is also carried out if there is a promise that has not been fulfilled, causing anger to the rulers of nature and inflicting disaster. Efforts to clean or purify the indigenous people of Moronene Hukaea Laea for the violations that have occurred are the duties of customary institutions. Customary institutions routinely carry out village purification ceremonies to ensure that the community and the customary environment are good.

\section{The Effect of Strengthening the Role of Traditional Institutions on Knowledge Preservation to Maintain the Sustainability of the Moronene Hukaea Laea Indigenous People}

One of the elements that must be fulfilled for the recognition of indigenous peoples is the existence of customary institutions that have the function of managing and regulating indigenous peoples. Local wisdom so that it does not become extinct, it must be preserved, especially by customary institutions as institutions that have the authority to regulate indigenous peoples. Globalization causes indigenous peoples to become one of the parties affected by foreign cultures that can influence local wisdom. Indigenous

\footnotetext{
22 Interviews with members of the Moronene indigenous peoples Hukaea Laea, Kasman and Sumarlan, 31 October 2020.

23 Interview with Moronene indigenous law community member Hukaea Laea, Alias, 31 October 2020.
}

peoples as supporters of culture are one of the determining factors for cultural preservation, for this reason the role of traditional institutions is very important to minimize the influence of foreign cultures that are incompatible with the personality of the Indonesian people $\left[{ }^{24}\right]$.

Hardjasoemantri $\left[{ }^{25}\right]$ stated that the role of customary institutions is as a medium of valuable information for decision makers. The strengthening of the role of customary institution has a strong influence on the preservation of knowledge of the indigenous Moronene Hukaea Laea people, especially knowledge of how to maintain their survival as part of the identity of indigenous people. The role of customary institution is mostly carried out by customary leader (mokole) as a symbol of leadership who is respected and obeyed by the indigenous Moronene Hukaea Laea community. Strengthening the role of customary institutions has an internal and external influence on the preservation of knowledge about maintaining survival, namely:

\section{Influence Internally}

Internal influence, namely customary institution has an influence on the survival of indigenous people. Internally, customary institution is an important requirement of indigenous people. Customary institution has the central role in preserving indigenous people's knowledge through the implementation of tradition or traditional ceremony at every moment. Customary institution becomes places to get facilities to meet the living needs of indigenous community members, such as land needs for gardening, especially for community members who have family. The communal nature of customary land means that customary institution regulates who members of the customary community, it can be granted management rights over customary land. The rights given to customary land are not ownership rights because the owner of the land is the customary community as a whole (public/communal ownership).

Customary institution becomes a means of "storing" all local knowledge or wisdom possessed by indigenous people. Knowledge of how to maintain survival is known by all members of indigenous people.

\footnotetext{
24 Christeward Alus, 2014, The Role of Traditional Institutions in Preserving Local Wisdom of the Sahu Tribe in Balisoan Village, Sahu District, West Halmahera Regency, Journal of "Acta Diurna" Volume III. No.4. 2014, p. 14., file: /I/ C: / Documents\% 20and\% 20Settings / Administrator / My\% 20Documents / Downloads / 5995-11653-1-SM\% 20 (1) .pdf., Accessed on 7 November 2020.

${ }^{25}$ Augustine Lumangkun Aris and Joko Nugroho.R., The Role of Customary Institutions in Resolving Land Conflicts in Customary Forests in Engkode Village, Mukok District, Sanggau Regency, jurna.untan.ac.id., P. 342.file: I// C: /Documents\%20and\%20Settings/Administrator/My\%20Docu ments/Downloads/7152-23760-1-PB.pdf., Accessed on 7 November 2020.
} 
Customary institution has a role to keep all knowledge about values in order to maintain the balance of human and natural (cosmic) relationship, use them for the benefit of indigenous people, to improve the welfare of indigenous people, maintain order in its customary territorial, and protect indigenous people from outside influences.

\section{Influence Externally}

Externally, the customary institution has influence outside the customary territory that represents the interests of indigenous people $\left[{ }^{26}\right]$. Externally, strengthening the role of customary institution is carried out by formulating the position of customary institution in regional regulation. A customary institution is an institution that has a sociological, magical and cultural basis. The institution of the Moronene Hukaea Laea indigenous people has been specifically regulated in the Bombana District Regulation of 4 of 2015, as a legal basis for recognition of the Moronene Hukaea Laea indigenous people by the State.

Implementing customary law, customary institutions become symbols of indigenous peoples. A tradition that must be carried out includes the rules for land clearing procedures (mo'ooli), village purification (montewehi) and harvest festivals, and welcoming the planting year. The head of the Hukaea Laea Moronene Customary Institution, namely Mansur Lababa on a regular and scheduled basis, has held ceremonies / traditions as a legacy of the ancestors of the Moronene people. Various parties from outside the customary territory are often invited to witness the adat procession. The procession is always documented in the form of photos and videos to become archives of the Moronene indigenous people as well as local government archives.

Customary institution becomes representatives of indigenous people in communicating about indigenous people. The Regulation of 4 of 2015 is the result of the struggle of the Head of Customary Institution to gain recognition from the Indonesian Government. Customary territory needs strengthening in the State to protect the existence of the Moronene Hukaea Laea indigenous people. Moronene customary institution has an important role in preserving the knowledge of the Moronene Hukaea Laea indigenous people to maintain its survival while maintaining the balance of the cosmic relationship between human and nature.

\section{Closing}

The form of strengthening the role of traditional institution through preservation of knowledge about maintaining the survival of the Moronene Hukaea Laea Indigenous People, namely routinely carrying out tradition or traditional ceremony that has been passed down from generation to generation including ceremonies for releasing the harvest year and welcoming the planting year (mewusosoi), ceremony to request permission on forest guard (ntiwonua) before land clearing (mo'ooli) and village purification ceremonies (montewehi) as well as supervision of customary institutions for customary violations which can be sanctioned by customary institution according to customary rule. The effect of strengthening the role of customary institution on the preservation of knowledge about maintaining the survival of the Moronene Hukaea Laea Customary Law Community is divided into internal and external influences. The effect of strengthening the role of customary institutions internally will be able to improve the welfare of customary law communities and externally will protect the existence of customary law community.

The strengthening of the role of customary institution must be supported by local government to always respect and appreciate the ability of indigenous people to organize and to maintain knowledge for survival without disturbing the balance between human and nature. Support from the local government of Bombana Regency, Indonesia and the community to strengthen the role of customary institution, provides benefit in efforts to conserve the environment, especially forests because customary institution has the authority to regulate the use of customary forest areas.

\section{ACKNOWLEDGMENT}

Researchers would like to thank various parties who helped, so that this research can be carried out well. Especially thanks to the Chancellor of Halu Oleo University; Dean of the Faculty of Law, Halu Oleo University; and Indigenous Leader of the Moronene Hukaea Laea. They have all provided moral and material assistance, so that we can finalize the results of this research.

\footnotetext{
26 Inosentius Samsul, 2014, Strengthening Customary Institutions as Alternative Institutions for Dispute Resolution (Studies on Customary Institutions in Banyu Asin Regency, South Sumatra and in Papua Province), Journal of NEGARA HUKUM: Vol. 5, No. 2, November 2014, p. 137, file: /// C: /Documents\%20and\%20Settings/Administrator/My\%20Docu ments/Downloads/237-468-1-SM.pdf., Accessed November 8,
} 2020. 